Bradycardia and asystole with the use of vagus nerve stimulation for the treatment of epilepsy: a rare complication of intraoperative device testing. Epilepsia 1999;40:1452-1454.

71. Tatum WO, IV, Moore DB, Stecker MM, et al. Ventricular asystole during vagus nerve stimulation for epilepsy in humans. Neurology 1999;52:1267-1269.

72. Davis AB, Dreyfuss MS. The finest instruments ever made: a bibliography of medical, dental, optical, and pharmaceutical company trade literature; 1700-1939. Arlington, MA: Medical History Publishing Associates, 1986.
73. Edmonson JM. American surgical instruments: an illustrated history of their manufacture and a directory of instrument makers to 1900. San Francisco: Norman Publishing, 1997.

74. Lombard JS. Experiments on the relation of heat to mental work. New York Med J 1867;5:198-205.

75. Lombard JS. Description of a new portable thermo-electric apparatus for medical and physiological investigations. BMJ $1875 ; 1: 98-102$.

76. Bastian. Dr. Lombard's thermo-electric apparatus. BMJ 1875; $1: 116$.

Neuro Images
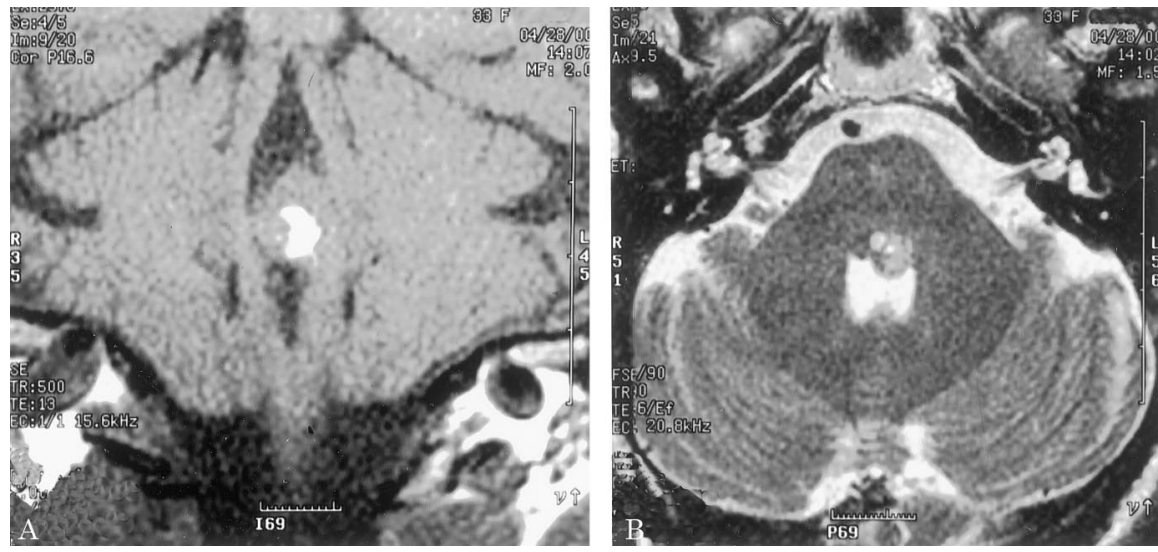

Figure. MRI of the brainstem (coronal T1-weighted image [A] and axial T2weighted image [B]) demonstrate a hemorrhagic lesion expanding the left facial colliculus. The appearance is most consistent with a cavernous malformation. It was angiographically occult, as is typical for these lesions.

\section{Cavernous malformation of the facial colliculus}

Sean M. Lew, MD, Sami Khoshyomn, MD, Robert W. Hamill, MD, Bruce I. Tranmer, MD, Burlington, VT

A 33-year-old woman presented with acute-onset diplopia and facial droop. Examination revealed a complete left lateral gaze palsy. The eyes could not be driven past midline to the left with rapid head rotation, opticokinetic drum, smooth pursuit, convergence, or saccades. A left peripheral facial palsy was present. No other deficits were appreciated. On MRI a solitary cavernous malformation expanded the left facial colliculus (figure). A suboccipital craniotomy was performed which revealed a firm, well- circumscribed, lobulated purplish lesion with surrounding hemosiderin- stained gliotic brain. The lesion was completely resected, and a cavernous malformation was confirmed by histology. Ocular motility and seventh nerve function gradually improved, and the patient was neurologically intact 3 months after surgery. Microsurgical resection of brain stem cavernous malformations has been met with favorable results in larger series and is advocated as a primary treatment for symptomatic lesions. ${ }^{1,2}$

1. Sindou M, Yada J, Salord F. Functional results after microsurgical resection of brain stem cavernous malformations (retrospective study of a 12 patient series and review of the recent literature). Acta Neurochir 2000; 142:843-852.

2. Ziyal IM, Sekhar LN, Salas E, Sen C. Surgical management of cavernous malformations of the brain stem. Br J Neurosurg 1999;13:366-375. 


\section{Neurology}

\section{Cavernous malformation of the facial colliculus}

Sean M. Lew, Sami Khoshyomn, Robert W. Hamill, et al.

Neurology 2002;58;459

DOI 10.1212/WNL.58.3.459

\section{This information is current as of February 12, 2002}

\section{Updated Information \&} Services

\section{References}

Permissions \& Licensing

Reprints including high resolution figures, can be found at: http://n.neurology.org/content/58/3/459.full

This article cites 2 articles, 0 of which you can access for free at: http://n.neurology.org/content/58/3/459.full\#ref-list-1

Information about reproducing this article in parts (figures,tables) or in its entirety can be found online at:

http://www.neurology.org/about/about_the_journal\#permissions

Information about ordering reprints can be found online:

http://n.neurology.org/subscribers/advertise

Neurology ${ }^{\circledR}$ is the official journal of the American Academy of Neurology. Published continuously since 1951, it is now a weekly with 48 issues per year. Copyright . All rights reserved. Print ISSN: 0028-3878.

Online ISSN: 1526-632X.

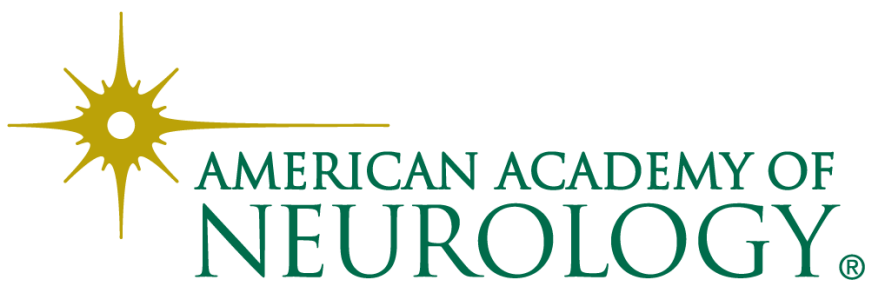

